\title{
Performance Analysis on the Effect of Doping Concentration in Copper Indium Gallium Selenide (CIGS) Thin-film Solar Cell
}

\author{
S M Shamim \\ Department of \\ Information and \\ Communication \\ Technology, \\ Mawlana Bhashani \\ Science and Technology \\ University, \\ Santosh, Tangail, \\ Bangladesh.
}

\author{
Angona Sarker \\ Department of \\ Information and \\ Communication \\ Technology, \\ Mawlana Bhashani \\ Science and Technology \\ University, \\ Santosh, Tangail, \\ Bangladesh.
}

\author{
Md. Rasel Ahmed \\ Department of \\ Information and \\ Communication \\ Technology, \\ Mawlana Bhashani \\ Science and Technology \\ University, \\ Santosh, Tangail, \\ Bangladesh.
}

\author{
Md. Fazlul Huq \\ Department of Nuclear \\ Engineering, \\ University of Dhaka, \\ Dhaka - 1000 \\ Bangladesh.
}

\begin{abstract}
A comparative investigation in the cell performance of Copper Indium Gallium Selenide (CIGS) thin-film solar cell has been reported. The main objective behind our work is to present the effect of the doping concentration on each layer i.e. window layer $(\mathrm{ZnO})$, buffer layer $(\mathrm{CdS})$ and absorption layer (CIGS) in the CIGS solar cell to find out the optimum doping concentration using ADEPT 2.0, a 1D simulation software. The device parameters are optimized separately for each layer. Energy conversion efficiency is calculated from light $\mathrm{J}-\mathrm{V}$ characteristics curve. A total-area efficiency of $19.75 \%$ for $\mathrm{ZnO}: \mathrm{Al} / \mathrm{i}-\mathrm{ZnO} / \mathrm{CdS} / \mathrm{CIGS}$ based thin-film solar cells has been reported.
\end{abstract}

\section{Keywords}

CIGS, Window layer, Buffer Layer, Absorption layer, Adept 2, Thin-film solar cell.

\section{INTRODUCTION}

A solar cell is an electronic device which directly converts sunlight into electricity. Light shining on the solar cell produces both a current and a voltage to generate electric power. CIGS is one of most promising materials for thin film photovoltaic devices because of its appropriate band gap and high absorption coefficient for solar radiation [1]. In recent years, improvements of the performances of the photovoltaic cells allow to obtain high conversion efficiency at relatively lower cost [2]. CIGS is a direct band gap material and highest efficiency among all commercially significant thin film materials. CIGS solar cell has the best conversion efficiency of thin film solar cells [3]. Several groups have achieved efficiency exceeding $18 \%$ in CIGS solar cells $[4,6]$.

A CIGS solar cell is built up of a substrate glass, a back contact of molybdenum (Mo), a light absorbing layer of CIGS, a buffer layer of cadmium sulphide (CdS), a thin layer of resistive zinc oxide $(\mathrm{ZnO})$ and a transparent front contact of aluminum doped zinc oxide ( $\mathrm{ZnO}: \mathrm{Al})$.This thin films solar cells have largest efficiencies on the laboratory scale [7] and as well as on the level of large-area modules [8]. Moreover its thin-film modules exhibit excellent outdoor stability [9] and radiation hardness $[10,11]$. Therefore, this combination of high efficiency coupled with stability and radiation hardness makes CIGS a promising material for the low cost, high efficiency solar cells. Figure 1 show schematic diagram of the CIGS solar cell.

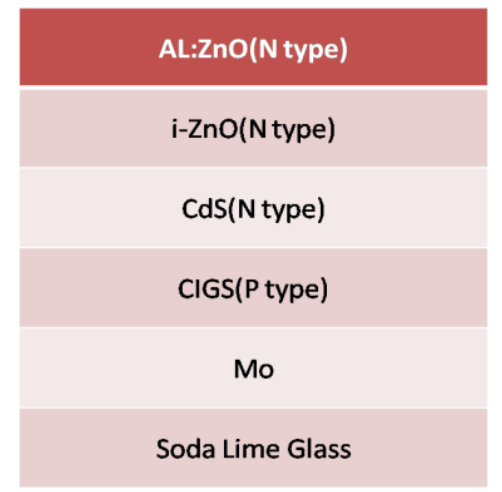

Fig-1: Schematic diagram of the CIGS solar cell

In CIGS solar cells, Al-doped $\mathrm{ZnO}$ ( $\mathrm{ZnO}: \mathrm{Al})$ films were used as transparent conducting window layers [12].The $\mathrm{n}$-type $\mathrm{CdS}$ buffer layers on CIGS absorbers are used in order to form a heterojunction with the p-type CIGS and to protect the CIGS surface from ion damage.

In this study, we will investigate the effect of the different doping concentration on each layer including $\mathrm{ZnO}$ layer, $\mathrm{CdS}$ buffer layer and CIGS absorption layer on the performance of the CIGS solar cell.

\section{EXPERIMENTAL}

In this research, device parameters (doping concentration) are optimized for each layer of the device. This was done by varying a particular parameter of a device layer, while keeping every other device parameter fixed at some default value, and observing the changes in the output light $\mathrm{J}-\mathrm{V}$ characteristics. The aim of this research is to investigate the effect of different ( $\mathrm{ZnO} / \mathrm{CdS} / \mathrm{CIGS}$ layer) layer doping concentration on the performance of the CIGS solar cell structure. All the simulations conducted for this work were done by ADEPT/F [13]. While conducting the research, initially we have chosen a set of default values of doping concentration for each layer of the device (as shown in Figure 1). These default values are listed in table 1 . 
Table-1: Default Values of Device Parameters for the Hetero-junction CIGS Solar Cell

\begin{tabular}{|c|c|c|c|}
\hline $\begin{array}{c}\text { Device } \\
\text { Parameters }\end{array}$ & $\begin{array}{c}\text { Top } \\
\text { Layer(ZnO) }\end{array}$ & $\begin{array}{c}\text { Middle } \\
\text { Layer(CdS) }\end{array}$ & $\begin{array}{c}\text { Bottom } \\
\text { Layer(CIGS) }\end{array}$ \\
\hline $\begin{array}{c}\text { Layer } \\
\text { Thickness }(\mu \mathrm{m})\end{array}$ & 0.8 & 0.05 & 3 \\
\hline $\begin{array}{c}\text { Doping Type } \\
\text { Doping } \\
\text { Conc. }\left(\mathrm{cm}^{-3}\right)\end{array}$ & $\mathrm{N}$ type & N type & P type \\
\hline
\end{tabular}

Simulation was conducted with these default values, and a light I-V characteristics graph was obtained. From the graph, values of open-circuit voltage (Voc) and short-circuit current density $\left(\mathrm{J}_{\mathrm{sc}}\right)$ were obtained. Fill factor (FF) and efficiency $(\eta)$ were calculated. This efficiency is the efficiency under AM1.5G illumination.

Initially, thickness of Aluminum doped zinc oxide ( $\mathrm{ZnO}: \mathrm{Al}$ ) layer is $55 \mathrm{~nm}$ and doping concentration is $5 \times 10^{18} \mathrm{~cm}^{-3}$. Thickness of zinc oxide $(\mathrm{ZnO})$ is $800 \mathrm{~nm}$ and doping concentration is $1 \times 10^{18} \mathrm{~cm}^{-3}$. The buffer layer (CdS) thickness and doping concentration is $52 \mathrm{~nm}$ and $1 \times 10^{17} \mathrm{~cm}^{-3}$. Absorption layer (bottom layer) thickness and doping concentration is $3000 \mathrm{~nm}$ and $1 \times 10^{16} \mathrm{~cm}^{-3}$ respectively. For the rest of the layers the standard parameters [14] were used. Figure 2 below shows the light $\mathrm{J}-\mathrm{V}$ characteristics graph obtained for this design.

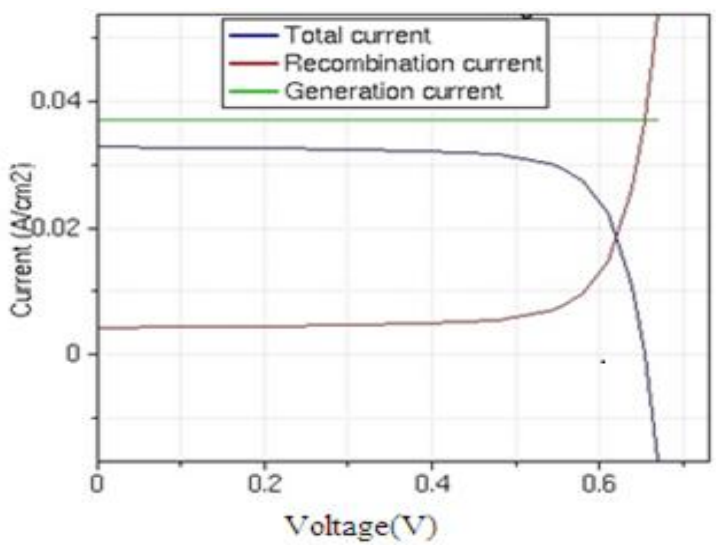

Fig-2: Light J-V characteristics for the first design

Figure 2 shows the initial design yields an open-circuit voltage $\left(\mathrm{V}_{\mathrm{oc}}\right)$ of $0.68 \mathrm{~V}$ and the short circuit current density $\left(\mathrm{J}_{\mathrm{sc}}\right)$ is $32.95 \mathrm{~mA} / \mathrm{cm}^{2}$. The fill factor was calculated to be 0.8427 . The efficiency was calculated $\eta=18.87 \%$.

\section{RESULT AND DISCUSSION}

The doping level of the n-type top layer was varied within a range of $1 \times 10^{18} \mathrm{~cm}^{-3}$ to $8 \times 10^{18} \mathrm{~cm}^{-3}$, and efficiency was calculated for each different value. It is to be noted that all other device parameters, including the layer thickness values, were kept as default.

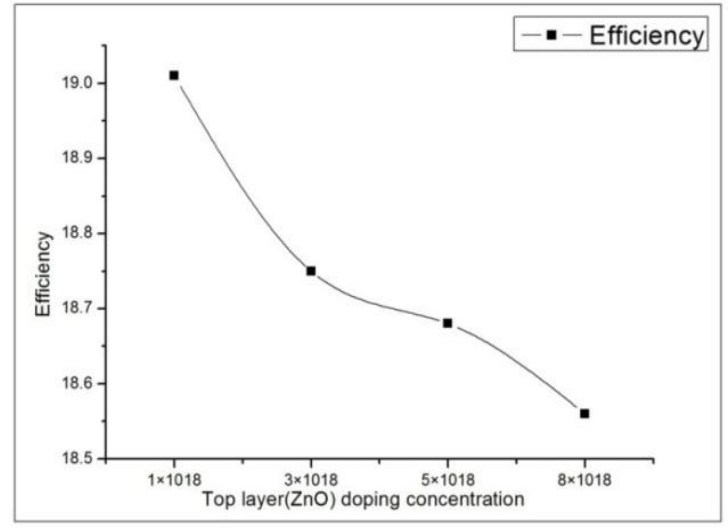

Fig-3: Efficiency response for different $\mathrm{ZnO}$ top layer doping concentration

A graph of efficiency versus top layer doping level is shown in Figure 3. It is evident from the figure that the efficiency decreases with increasing doping concentration in the top layer.

The electric field in the space charge region decreases with the increasing doping in the top layer which decreases the drift velocity of the majority carriers. The short circuit current keeps on increasing significantly, as the doping increases in the top layer. So, for optimization, the top layer doping level should be kept as low as possible. Now, the doping concentration in the middle layer was varied (from $1 \times 10^{17} \mathrm{~cm}^{-}$ ${ }^{3}$ to $\left.8 \times 10^{17} \mathrm{~cm}^{-3}\right)$, keeping every other device parameter as default.

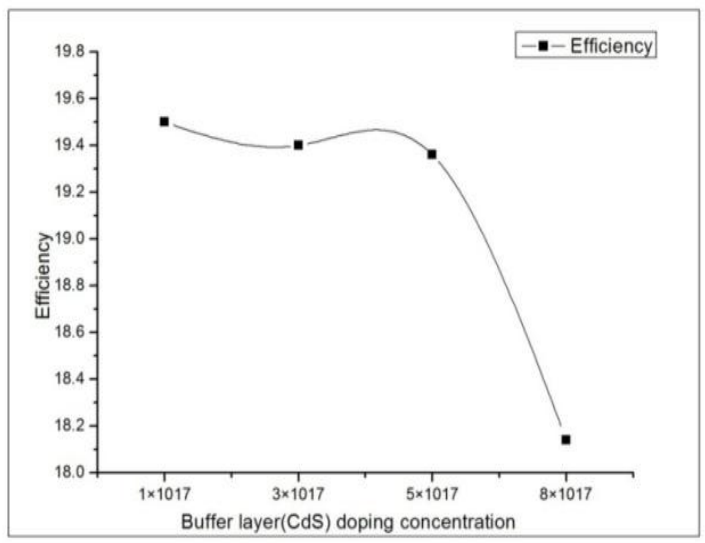

\section{Fig-4: Efficiency response for different middle layer} doping concentration

It is evident from the figure 4 that the efficiency decreases with increasing doping concentration in the middle layer. High doping in buffer layer has a strong negative effect on the output current in the CIGS solar cell due to increased minority carrier recombination rate. This negative impact cannot be compensated by the increased electric field at high doping in buffer layer. As a result, the output current decreases with increased doping in the buffer layer. So we restrict the optimized doping level in the base to $1 \times 10^{17} \mathrm{~cm}^{-3}$.

To understand the effect of variation in bottom layer doping level on the efficiency, simulations were conducted with varying bottom layer doping concentrations (from $1 \times 10^{16} \mathrm{~cm}^{-3}$ to $8 \times 10^{16} \mathrm{~cm}^{-3}$ ). 


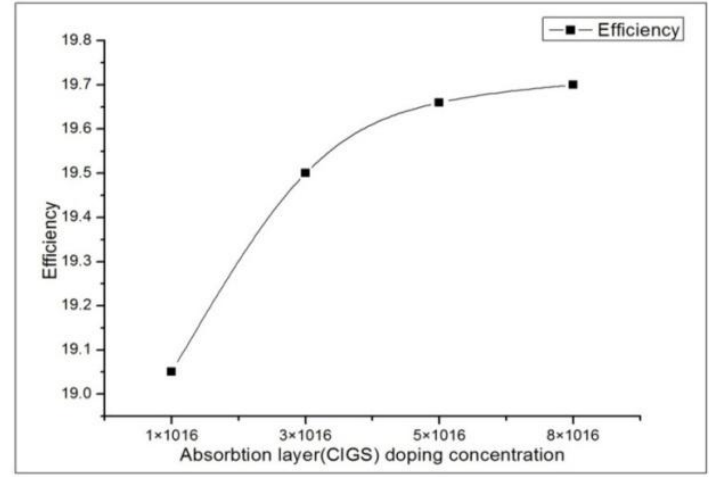

Fig-5: Efficiency response for different bottom layer doping concentration

Figure 5 shows a plot of efficiency versus bottom layer doping level. From the figure, it is evident that the efficiency increases with increasing doping level in the bottom layer. The increased doping in the bottom layer increases the electric field in the space-charge region, which, in turn, increases the drift velocity of the majority carriers. This increased drift velocity increases the output current. But at the same time, a higher doping level at the bottom layer increases the minority carrier recombination rate, which reduces the output current. So, the change in output current depends on which of these two factors dominates the other at a particular doping concentration. This implies that at increased doping, the increased electric field has a much stronger effect than the minority carrier recombination. So, for optimization, the top layer doping level should be relatively higher.

\section{OPTIMUM RESULT}

From the analysis of the efficiency variation curves and the outcomes it is obvious that in order to achieve the maximum possible efficiency from the $\mathrm{ZnO} / \mathrm{CdS} /$ CIGS hetero-junction solar cell, on $\mathrm{ZnO}$ doping concentration should be kept 1 $\times 10^{18} \mathrm{~cm}^{-3}$. Buffer layer doping concentration should be kept $1 \times 10^{17} \mathrm{~cm}^{-3}$. In the absorption layer doping concentration should be $8 \times 10^{16} \mathrm{~cm}^{-3}$. To obtain optimum efficiency from the solar cell, the doping concentration of different layers is summarized in Table 2 .

Table-2: Optimum Simulation Results for CIGS Heterojunction Solar Cell

\begin{tabular}{|c|c|}
\hline Layer & Doping Concentration \\
\hline $\mathrm{ZnO}$ & $\mathrm{N}_{\mathrm{d}}=1 \times 10^{18} \mathrm{~cm}^{-3}$ \\
\hline $\mathrm{CdS}$ & $\mathrm{N}_{\mathrm{d}}=1 \times 10^{17} \mathrm{~cm}^{-3}$ \\
\hline $\mathrm{CIGS}$ & $\mathrm{N}_{\mathrm{a}}=8 \times 10^{16} \mathrm{~cm}^{-3}$ \\
\hline
\end{tabular}

Figure 6 shows optimum light J-V characteristics for CIGS hetero-junction solar cell where optimum doping concentration is used for each layer.

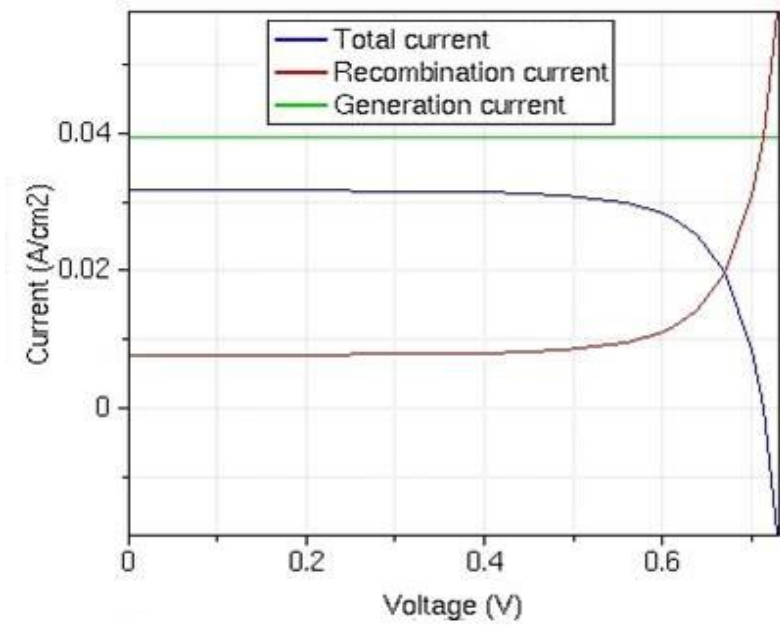

Fig-6: Light J-V characteristics of the CIGS thin-film solar cells fabricated using optimum doping concentration of each layer

From Figure 6, it is found that the resulting open-circuit voltage ( $\mathrm{Voc}$ ) is $0.73 \mathrm{~V}$, and the short circuit current density $\left(\mathrm{J}_{\mathrm{sc}}\right)$ is $31.8 \mathrm{~mA} / \mathrm{cm}^{2}$. The fill factor (FF) is calculated to be 0.8506 , and the calculated efficiency $(\eta)$ is $19.75 \%$.

\section{CONCLUSIONS}

We have used ADEPT 2.0 to investigate the dependence of doping concentration in CIGS thin films solar cells. We have seen that energy conversion efficiency decreases with increasing doping concentration in the window layer $(\mathrm{ZnO})$ and efficiency decreases with the increasing doping concentration in the buffer layer (CdS). We have also observed that efficiency increases with increasing doping level in the absorption layer (CIGS).The effect of doping concentration play significant role on the performances of the CIGS solar cell ( $\mathrm{ZnO} / \mathrm{CdS} / \mathrm{CIGS})$ structures. The optimum conversion efficiency is $19.75 \%$ observed. From these results, it can be concluded that doping concentration is an effective technique for improving the conversion efficiency of CIGS thin-film solar cells.

\section{REFERENCES}

[1] T. Wada, Y. Hashimoto, S.Nishiwaki, T.Satoh, S. Hayashi, T. Negami, \& H.iyake,. High-efficiency CIGS solar cells with modified CIGS surface.Solar Energy Materials and Solar Cells, 67(1), 305-310(2001).

[2] M.Benosman, F. Dujardin ,J. P. Charles , \& B.Benyoucef,. The Effect Doping $\mathrm{p}$ of the Oxide Layer on the Performances of Photovoltaics Thin Films Structures. Journal of Electron Devices, 2, 53-56(2003).

[3] M.Fathil, M. K.Arshad, U.Hashim, A. R.Ruslinda, R. M.Ayub, A. H.Azman, \& A. R.Munir, (2014, August). The impact of minority carrier lifetime and carrier concentration on the efficiency of CIGS solar cell. InSemiconductor Electronics (ICSE), 2014 IEEE International Conference on (pp. 24-27). IEEE.

[4] M.A. Contreras, B. Egaas, K. Ramanathan, J. Hiltner, A. Swartzlander, F. Hasoon, R. Nou", Prog. Photovol. 7 (4) 311(1999).

[5] T. Negami et al., Presented at the 11th Photovoltaic Science Engineering Conference, Sapporo (1999). 
[6] Y. Hagiwara, T. Nakada, A. Kunioka, Technical Dig. 11th Photovoltaic Science Engineering Conference, pp. 83,84 (1999)

[7] Repins, M.A. Contreras, B. Egaas, C. DeHart, J. Scharf, C.L. Perkins, B. To, R. Noufi, Prog. Photovolt: Res. Appl. 16, 235 (2008).

[8] C. Lombardi, (http://www.miasole.com/sites/default/files/Cnet_Dec_0 2_2010.pdf) (2010).

[9] H.S. Ullal, K. Zweibel, B.V. Roedern, Proceedings of the 26th IEEE Spec. Conference, IEEE, art. No. 2012 (1997).

[10] M. Yamaguchi, J. Appl. Phys. 78, 1476 (1995)
[11] H.W. Schock, K. Bogus, in: J. Schmid, H.A. Ossenbrink, P. Helm, H. Ehmann, E.D. Dunlop (Eds.), Proceedings of the 2nd World Conference on Photovoltaic Energy Conversion, E.C. Joint Research Centre, Luxemburg, art. No. 3586 (1998).

[12] Hagiwara, Y., Nakada, T., \&Kunioka, A.. Improved J sc in CIGS thin film solar cells using a transparent conducting ZnO: B window layer. Solar Energy Materials and Solar Cells, 67(1), 267-271 (2001).

[13] Gray, J.L., and Michael McLennan. Adept. [Online]. Available: http://nanohub.org/resources/adept/ , 2008.

[14] M. Gloeckler, A.L. Fahrenbruch, J.R. Sitesm, Proceedings of 3rd World Conference on Photovoltaic Energy Conversion, 491 (2003). 